\title{
Bipolar Bozukluk Tanısı ile İzlenen Hastalarda İşlevsellik ve Kişilik Özelliklerinin Koruyucu Tedavi Üzerine Olan Etkisinin İncelenmesi
}

\section{Effect of personality traits on functioning and long-term treatment in patients with bipolar disorder}

iD Çağdaş Hünkar Yeloğlu1 ${ }^{1}$ iD Çiçek Hocaoğlu ${ }^{2}$, iD Bülent Bahçeci²

${ }^{1}$ Uzm. Dr., Kozan Devlet Hastanesi Psikiyatri Kliniği, Adana

${ }^{2}$ Recep Tayyip Erdoğan Üniversitesi Psikiyatri Anabilim Dalı, Rize

\section{$\ddot{O} z$}

Amaç: Bipolar bozukluk (BB) oldukça önemli bir sağlık sorunu olup, ciddi sosyal ve ekonomik sonuçlar doğurmaktadır. BB tanılı olguların koruyucu sağaltımının etkin şekilde planlanması ve hastanın yaşam kalitesinin en iyi düzeyde tutulması tedavinin ana hedefidir. Çalışmamızda BB tanısı ile izlenen hastalarda, kişilik özelliklerine göre işlevsellik ile koruyucu sağaltıma verilen yanıt düzeylerinde bir farklılık olup olmadığının belirlenmesi amaçlanmıştır.

Gereç ve Yöntem: Çalışmaya ayaktan tedavi biriminde takip edilen ve çalışmaya katılmak için gönüllü olan BB tanılı 80 hasta dahil edilmiştir. Tüm olgulara Bipolar Bozukluk İşlevsellik Ölçeği (BBïÖ), Young Mani Derecelendirme Ölçeği (YMDÖ), Hamilton Depresyonu Derecelendirme Ölçeği(HDDÖ), Eysenck Kişilik Anketi-Gözden Geçirilmiş Kısaltılmış Formu-(EKA-GGK) ve Koruyucu Sağaltım Değerlendirme Ölçeği (KSDÖ) uygulanmıştır.

Bulgular: Çalışmaya katılan hastaların 57'si kadın (\%71.3), 23’ü (\%28.7) ise erkekti. Psikotisizm kişilik boyutu ile koruyucu sağaltıma yanıt arasında zayıf ancak, anlamlı negatif bir ilişki olduğu saptandı. Diğer kişilik boyutları incelendiğinde ise aralarında anlamlı bir ilişki bulunamadı.

Sonuç: Koruyucu Sağaltım Değerlendirme Ölçeği'nin kullanılabilirliği ile ilgili daha fazla çalışmaya ihtiyaç vardır. Bipolar bozuklukta kişiye en uygun koruyucu sağaltımı olabildiğince erken belirlemek önemli bir hedeftir. Kişilik özelliklerinin bu anlamda belirleyici rolünün yerinin ve büyüklüğünün tam olarak saptanması amacıyla yeni çalışmalara ihtiyaç vardır.

Anahtar kelimeler: Bipolar Bozukluk, koruyucu sağaltım, işlevsellik, kişilik özellikleri

Abstract

Objective: Bipolar disorder (BD) is a very important health problem and has serious social and economic consequences. The main goal of the treatment is to regulate the most effective and optimal quality of life of the patients with the diagnosis of BD. In our study, we aimed to determine whether there is a difference in scores of functionality and long-term treatment response degrees related to personality traits.

Materials and Methods: Eighty patients with bipolar disorder who were followed up in an outpatient unit and volunteered to participate in the study were included in the study. Bipolar Disorder Functioning Scale (BDFS), Young Mania Rating Scale (YMRS), Hamilton Depression Rating Scale (HDRS), Eysenck Personality Questionnaire Revised-Short Form (EPQR-S) and Long-term Treatment Responce Scale (ALDA) were administered to all subjects.

Results: 57 (71.3\%) patients of the sample was woman and 23(28.7\%) of them was man. It appears that there is a weak but significant negative correlation between psychotisizm dimension and response to the long-term treatment. When we examined tha other aspects of the personality dimensions, no significant correlation was found.

Conclusions: It seems that there is a need for more studies about the convenience of ALDA. In bipolar disorder; determining the most suitable treatment plan, as early as it could be, for indivudials is a very important goal and in this context, there is a need for more studies to understand the decisive role of personality traits on treatment.

Key words: Bipolar Disorder, long-term treatment, functioning, personality traits

*Bu çalışma 15-19 Nisan 2015, Antalya'da düzenlenen Uluslararası Psikofarmakoloji Kongresi \& 2.Uluslararası Çocuk ve Ergen Psikofarmakolojisi Sempozyumu (7. UPK- 2.UÇEPS) poster bildiri olarak sunulmuştur.

Yazışma Adresi: Çiçek Hocaoğlu, RTEÜ Tıp Fakültesi Psikiyatri Anabilim Dalı, Rize

E-Posta: cicekh@gmail.com

Alınma Tarihi: 30.03.2020 / Kabul Tarihi: 24.06.2020 / Yayımlanma Tarihi: 20.09.2021

Bipolar Bozuklukta koruyucu tedavi ve işlevsellik - Yeloğlu ve ark.

Genel Tip Derg 2021;31(3)189-195 
Bipolar bozukluk (BB) depresif ve manik ya da hipomanik dönemlerin olduğu, dönemler arası tamamen normal olan ya da kalıntı belirtinin eşlik ettiği bir ruhsal bozukluktur. Sıklıkla kronik seyirli yineleyici özelliğinedeni ile yüksek mortalite, morbidite ve hemen her alanda işlev kaybına yol açabilir (1). Bipolar bozukluğun iki yıl içinde tekrarlama oranı $\% 60$ civarındadır (2). Bu nedenle hastalık dönemlerini önlemede sürdürüm ve koruyucu sağaltımın uygulanması bu hastalarda hayati önem arz etmektedir. Depreşme ve yinelemelerin önlenmesini ve eşik altı belirtilerin ortadan kaldırılmasını hedefleyen koruyucu sağaltım mortalite ve morbiditeyi düşürür ve hastaların yaşam kalitesini arttırır. Koruyucu sağaltım sırasında karşılaşılan en önemli sorunlardan biri tedavi uyumudur. BB tanılı hastalarda tedavi uyumsuzluğu oldukça sıktır ve duygudurum dönemlerinin yinelemesine yol açan nedenlerin başında gelir $(3,4)$. Koruyucu sağaltım yanıtını etkileyen başlıca etkenler arasında, erken tanı ve tedavi, eş tanılı diğer ruhsal bozuklukların varlığı ve kişilik özellikleri sayılabilir (5). Bazı kişilik özelliklerinin ve ağır kişilik bozuklukların varlığının, diğer birçok ruhsal bozukluklarda, hastalık gidişi, tedavi uyumu ve tedavi yanıtını olumsuz etkilediği bilinmektedir (6). Geçmişten günümüze kişilik özelliklerinin hastalık üzerine etkisi merak konusu olsa da, doğrudan bu konu üzerine yapılmış çalışma yok denecek kadar azdır. Bu nedenle farklı kişilik özellikleri gösteren gruplar arasında tedavi yanıtı açısından farkları belirlemek, konuyla ilgili literatürü ilerletmek ve tedaviye başlarken hastanın kişilik özelliklerine daha uygun tedaviyi önceden belirleyebilmek açısından yardımcı olacaktır. Çünkü kişilik özellikleri tedavinin seyrini ve işlevselliği etkileyebilir. Diğer yandan BB koruyucu sağaltımı ile ilgili çok sayıda çalışma literatürde yer almasında karşın, bu gün hala tartışmaya açık pek çok sorun da mevcuttur. Konu ile ilgili her geçen gün yeni koruyucu sağaltım seçeneklerinin sunulmasına ve yeni tedavi algoritmalarının yayınlanmasında karşın, klinisyenler günlük tıbbi uygulamalarında halen ciddi zorluklar yaşamaktadır. Koruyucu sağaltımın en etkin ve hastanın yaşam kalitesini en uygun şekilde düzenlenmesi tedavinin ana hedefidir. Bu nedenle koruyucu sağaltımın değerlendirilmesinin nesnel olması ve somutlaştırılmasını önemlidir. Günümüze kadar olan süre içinde koruyucu sağaltıma yanıtı ölçme ve değerlendirme yöntemleri değişkenlik göstermiş, yanıta etki edebilecek ya da yanıtı ölçebilecek nesnel, geçerliliği ve güvenilirliği yüksek olan ölçekler geliştirilmeye çalışılmıştır $(7,8)$. Bugün halen konu ile ilgili bilgilerin yeterli olduğunu söylemek mümkün değildir ve bu alanda yapılacak her çalışmanın sonucu son derece önemlidir.

Bizim çalışmamızda BB tanılı hastalarda koruyucu sağaltımın etkileyebileceği düşünülen kişilik özelliklerinin işlevsellik ve koruyucu sağaltım üzerindeki etkisi değerlendirilerek, mevcut yazına katkı sunulması amaçlanmıştır.

\section{Gereç ve Yöntemler}

\section{Örneklem}

Çalışmaya 1.2.2013-1.1.2014 tarihleri arasında Recep Tayyip Erdoğan Üniversitesi Rize Eğitim ve Araştırma Hastanesi Psikiyatri Polikliniğine ardışık sıra ile başvuran ve DSM-IV-TR (Amerikan Psikiyatri Birliği 2000) ölçütlerine göre BB tip 1 ya da BB tip 2 tanıs1 konulan ve bu tanıyla en az 6 aydır izleniyor olan 18-65 yaş arası 80 hasta dahil edilmiştir. Olguların ölçeklerin uygulanması için yapılacak görüşmeyi sürdürebilecek seviyede konuşma ve kendilerini ifade etme becerilerine sahip, duygudurum dengeleyici ilaç kullanan ve ölçülebilir ilaç kan ilaç düzeylerinin terapötik düzeyde olması çalışmaya dahil edilme ölçütü olarak belirlenmiştir. Bu çalışmada yapılan tüm uygulamalar, kurumsal ve / veya ulusal araştırma komitesinin etik standartlarına ve 1964 Helsinki Bildirgesi'ne ve daha sonraki düzeltmelerine veya karşılaştırılabilir etik standartlara uygun yapılmıştır. Aktif hastalık döneminde olan BB tanılı hastalar, aktif psikozu olanlar, demans, mental retardasyon, parkinson hastalığı, dejeneratif hastalıklar, multiple skleroz gibi nörolojik hastalığı olanlar, genel olarak sistemik lupus eritamatozus (SLE), kronik böbrek yetmezliği v.b. sistemik kronik hastalığı olanlar çalışmaya dahil edilmemiştir. Dışlama ölçütleri arasında araştırma yönergesini anlama ve ölçekleri doldurmada sorun yaratacak bilişsel kusuru olması olarak belirlenmiştir. Remisyon evresi son 3 ayda herhangi bir duygudurum dönemi geçirilmemesi biçiminde tanımlanmıştır. Çalışma öncesi Recep Tayyip Erdoğan Üniversitesi Tıp Fakültesi Etik Kurulu'dan gerekli onay alınmıştır (18.3.2013 tarih 2013/16). Çalışmaya katılan tüm olgular çalışma hakkında bilgilendirilerek, yazılı aydınlatılmış onamları alınmıştır.

\section{Veri Toplama Araçları}

Sosyodemografik Veri Toplama Formu: Hastaların sosyodemografik özellikleri, hastalığın klinik özellikleri (hastanın kullandığı ilaç, ilaçlarını düzenli kullanıp kullanmadığı, belirli bir hekim ya da kurum tarafından düzenli olarak izlenip izlenmeme vb) gibi araştırmanın bağımsız değişkenleri konusunda bilgi edinmek amacıyla, literatür bilgilerinden yararlanılarak, çalışmacılar tarafından hazırlanmış olan bir anket formu kullanılmıştır.

DSM-IV Eksen I bozuklukları için yapılandırılmış klinik görüşme (SCID-I): First ve arkadaşları tarafından 1997'de DSMIV Eksen I bozuklukları için yapılandırılmış klinik görüşmedir (9). SCID-I tanısal değerlendirmenin standart bir biçimde uygulanmasını sağlayarak tanının güvenilirliğinin ve DSM-IV tanı ölçütlerinin taranmasını kolaylaştırarak tanıların geçerliğinin arttırılması, belirtilerin sistematik olarak araştırılması için geliştirilmiştir. SCIDI'in Türkiye için geçerlik ve güvenilirlik çalışmaları Çorapçığlu ve arkadaşları tarafından 1999'da yapılmıştır (10).

Young Mani Değerlendirme Ölçeği (YMDÖ): Bu ölçek, 11 maddeden oluşmakta ve her biri 5 aşamalı belirti şiddeti ölçmektedir (11). Ölçeğin Türkçe geçerlik ve güvenirlik çalışmasında iç tutarlık katsayıs $\% 79$ olarak bulunmuş, çalışmacıların ölçek maddeleri arasındaki fikir birliği \% 63.3-\% 95.5, kappa değerleri 0.114-0.849 arasında bulunmuştur (12).

Hamilton Depresyonu Derecelendirme Ölçeği (HDDÖ): Hastada depresyonun düzeyini ve şiddetini ölçer. On yedi maddeden oluşan ölçek Hamilton tarafından 1960 yılında geliştirilmiştir. Türkçe geçerlilik ve güvenilirlik çalışması Akdemir ve arkadaşları tarafından 1996 yılında yapılmıştır. Ölçeğin Türkçe formunun güvenilirliği, iç tutarlılık çalışmasında Cronbach alfa değerleri 0.75, Sperman Brown güvenilirlik katsayısı 0.76 'dır (13).

Bipolar Bozukluk İşlevsellik Ölçeği (BBİÖ): Türkçe için güvenilirlik ve geçerliği gösterilmiş olan Bipolar Bozukluk İşlevsellik Ölçeği 52-maddeli üçlü Likert tipi bir öz bildirim ölçeğidir ve 11 boyuttan oluşmaktadır (14). Yüksek puan iyi işlevselliği göstermektedir.

Koruyucu Sağaltımı Değerlendirme Ölçeği (KSDÖ): Grof ve 
arkadaşları tarafından geliştirilmiş bir ölçektir. 3 Koruyucu sağaltımın hastalık seyri üzerindeki iyileştirici etkisini (A ölçütü) klinik faktörleri (B ölçütleri) de hesaba katarak değerlendiren bir ölçektir (15). A ölçütü koruyucu sağaltım sırasında geçirilen duygudurum dönem sıklığını 0 ile 10 puan üzerinden değerlendirmektedir. B ölçütü ise 5 maddeden oluşur ve her maddeye verilen yanıta 0,1 ya da 2 puan verilir. B1 ölçütü koruyucu sağaltım öncesi dönem sayısını, B2 ölçütü dönem sıklığını değerlendirir. Bu iki maddeden alınan puanların yüksek olması hastanın etkin sağaltım görmediği durumda morbidite riskinin de yüksek olacağını gösterir. B3 ölçütü koruyucu sağaltımın süresini ölçer. Böylelikle düzelmenin ilaçtan bağımsız hastalığın doğal seyrine bağlı olup olmadığı değerlendirilmiş olur. B4 ölçütü koruyucu ilaca uyumu değerlendirir. B5 ölçütü ise ek sağaltım kullanımını ve düzelmenin ek sağaltıma bağlı olup olmadığını değerlendirir. B ölçütünün toplam puanı her maddeden alınan puanları toplamıyla saptanır. Ölçeğin toplam puanı B ölçütünden alınan puanın A ölçütünden alınan puandan çıkarılmasıyla saptanır. Toplam puan maksimum 10, minimum 0 olabilir. A ölçütünün 5'ten fazla olmas1 sağaltıma \% 50 yanıt verme olarak kabul edilirken toplam puanın 7 ve üstü olması tam yanıt kabul edilmektedir. Ölçeğin güvenilirliği son derece yüksektir, uygunluk oranı $\% 90$ ve kappa değeri 0.80 'dir.

Eysenck Kişilik Anketi- Gözden Geçirilmiş Kısaltılmış Formu (EKA-GGK): Francis ve ark. (1992), Eysenck Kişilik Anketi ve aynı anketin kısa formunu (48 madde) gözden geçirerek EKA-GGK'y1 oluşturmuştur (16). Anket, 24 madde olup, kişiliği 3 ana faktörde değerlendirmektedir: dişadönüklük, nörotisizm, psikotisizm. Her bir kişilik özelliği için alınabilecek puan 0 ile 6 arasında değişmektedir. Ülkemizde geçerlik ve güvenirliği yapılmıştır (17).

\section{İşlem}

Recep Tayyip Erdoğan Üniversitesi Tıp Fakültesi Eğitim ve Araştırma Hastanesi Psikiyatri Polikliniğinde BB tanısı ile izlenen olan hastalara çalışmanın amacı ve yöntemi hakkında bilgi verildi. Çalışmanın ölçütlerini karşılayan ve aydınlatılmış onam formunu doldurarak çalışmaya katılmayı kabul eden hastalara sosyodemografik veri toplama formu, YMDÖ, HDDÖ, KSDÖ, BBİÖ ve EKA-GGK araştırmacılar tarafindan uygulandi. Her hasta ile yalnız olarak gerçekleştirilen ve tek oturumda tamamlanan görüşme yaklaşık 60 dakika sürdü. Çalışmaya dahil edilen olguların ötimik dönemde olup/ olmadıkları YMDÖ, HDDÖ kullanılarak, ek psikiyatrik tanıları ise SCID-I kullanılarak değerlendirildi.

\section{İstatistiksel Analiz}

$\mathrm{Bu}$ araştırmada elde edilen veriler SSPS for Windows 22.0 (SPSS Inc, Chicago, IL) veri tabanı programına aktarılarak değerlendirilmiştir. Ölçümle elde edilen verilerin normal dağılıma uygunluğu, her bir grupta Kolmogorov Smirnov testi ile incelenmiştir. Normal dağılıma uyan değişkenlerin analizleri Student t testi ile; normal dağılıma uymayan değişkenlerin analizi ise Mann Whitney $U$ testi ile yapılmıştır. Niteliksel verilerin analizleri Ki-Kare testi ile yapılmıştır. Ölçümle elde edilen veriler aritmetik ortalama \pm standart sapma, sayımla elde edilen veriler ise sayı (\%) olarak gösterilmiştir. Anlamlılık düzeyi $\mathrm{p}<0.05$ olarak alınmıştır.

\section{Bulgular}

Çalışmaya alınan toplam 80 hastanın 57'si (\%71.3) kadın, 23'ü (\%28.7) erkekti. Yaş aralığı 18-74 yaş, yaş ortalaması $40.51 \pm 14.2$ idi. Hastaların \% 25'nin yükseköğretim, \% 41.3'nün ilk-ortaöğrenim düzeyine sahipti. Büyük çoğunluğunu ev hanımları tarafından (\%52.5) oluşturan örneklemin \%50'si evli, \%10 bekar, \%40'1 eşinden ayrılmıştı. Olgulardan 25 'inde (\%31.2) sırası ile obsesif kompulsif bozukluk (OKB), panik bozukluk, yaygın anksiyete bozukluğu gibi psikiyatrik eştanıların yer aldığı izlendi. Hastaların genel klinik özelliklerinin cinsiyete göre karşılaştırılması Tablo 1'de gösterilmiştir.

Tablo 1. Çalışma grubunu klinik özelliklerinin cinsiyete göre karşılaştırılması

\begin{tabular}{|c|c|c|c|c|}
\hline Değişken & Kadın $(n=57)$ & Erkek $(n=23)$ & $\chi^{2} / \mathrm{t}$ & p \\
\hline Yaş & $40.91 \pm 13.75$ & $39.52 \pm 15.74$ & 2.42 & 0.78 \\
\hline Tanı & & & 1.354 & 0.328 \\
\hline BB tip 1(n,\%) & $46(\% 80.7)$ & $21(\% 91.3)$ & & \\
\hline BB tip 2(n,\%) & $11(\% 19.3)$ & $2(\% 8.7)$ & & \\
\hline Aile Öyküsü(n,\%) & $25(\% 43.8)$ & $8(\% 34.7)$ & 0.557 & 0.455 \\
\hline Manik dönem sayısı (Ort_tss) & $3.4 \pm 6.3$ & $4.30 \pm 4.4$ & 0.33 & 0.604 \\
\hline $\begin{array}{l}\text { Depresif dönem sayısı } \\
\text { (Ort_tss) }\end{array}$ & $4.46 \pm 8.2$ & $4.78 \pm 6.3$ & 0.04 & 0.866 \\
\hline Mevsimsel Özellik (n,\%) & $25(\% 43.8)$ & $6(\% 26.0)$ & 2.181 & 0.205 \\
\hline Psikotik özellik (n,\%) & $30(\% 52.6)$ & $10(\% 43.4)$ & 0.549 & 0.622 \\
\hline Psikiyatrik eş tanı(n,\%) & $18(\% 31.5)$ & $7(30.4)$ & 0.738 & 0.675 \\
\hline İntihar girişimi & $14(\% 24.5)$ & $6(\% 26.0)$ & 0.20 & 0.548 \\
\hline Hastalık süresi (yıl) (Ort+ $+\underline{s s})$ & $14.63 \pm 9.4$ & $11.87 \pm 8.2$ & 1.52 & 0.200 \\
\hline $\begin{array}{l}\text { Hastalık başlangıç yaşı (yıl) } \\
\text { (Ort_tss) }\end{array}$ & $26.28 \pm 4.1$ & $27.65 \pm 3.9$ & 0.33 & 0.721 \\
\hline $\begin{array}{l}\text { Koruyucu tedavi alma süresi } \\
\text { (yll) (Ort_tss) }\end{array}$ & $8.72 \pm-6.1$ & $8.06 \pm 7.1$ & 2.42 & 0.744 \\
\hline $\begin{array}{l}\text { Hastaneye yatış sayısı } \\
(\text { Ort } \pm \text { ss) }\end{array}$ & $1.89 \pm 2.0)$ & $1.22 \pm 2.2$ & 1.14 & 0.222 \\
\hline
\end{tabular}

Çalı̧̧maya alınan 80 hastanın 36'sı (\%45) sadece lityum, 23'ü (\%28.8) yalnızca valproik asit, 3'ü (\%3.8) sadece lamotrijin, 1'i (\%1.3) yalnızca karbamazepin kullanıyordu. Hastaların 5'i (\%6.3) lityum ve lamotrijin, 5'i (\%6.3) lityum ve valproik asit, 1'i(\%1.3) lityum ve karbamazepin kullanıyordu. Lityum kullananların KSDÖ ortalama puanı $3.19 \pm 2.5$, valproik asit kullananların ise, $2.30 \pm 4.5$ 'idi. En düşük KSDÖ ortalama puanı $1.2 \pm 1.4$ olmak üzere lityum ve lamotrijin kullanan gruptaydı. Örnekleme uygulanan BBİÖ ortalama puanı $95.7+17.8$ bulundu. Hastaların BBİÖ ortalama puanlarının cinsiyete ve tanılara göre dağılımı Tablo 2'de gösterilmiştir.

Tablo 2. Çalışma grubunun BBİÖ ortalama puanlarının cinsiyete ve tanılara göre karşılaştırılması

\begin{tabular}{|l|l|l|l|l|l|l|}
\hline Ölçek & $\begin{array}{l}\text { Kadın } \\
(\mathbf{n}=\mathbf{5 7})\end{array}$ & $\begin{array}{l}\text { Erkek } \\
(\mathbf{n}=\mathbf{2 3})\end{array}$ & $\mathbf{p}$ & $\begin{array}{l}\text { BB tip 1 } \\
(\mathbf{n}=\mathbf{6 7})\end{array}$ & $\begin{array}{l}\text { BB tip 2 } \\
(\mathbf{n}=\mathbf{1 3})\end{array}$ & $\mathbf{p}$ \\
\hline $\begin{array}{l}\text { BBiÖ } \\
\text { (ort_SD) }\end{array}$ & $93.35 \pm 18.2$ & $101.65 \pm 15.6$ & 0.60 & $97.91 \pm 17.7$ & $84.54+14.7$ & 0.01 \\
\hline
\end{tabular}

Hastalara uygulanan EKA-GGKF sonucunda, nörotisizm alt boyutunda $3.14 \pm 1.3$, dişa-dönüklük alt boyutunda $1.84 \pm 1.6$, psikotisizm alt boyutunda ise $1.59 \pm 1.2$ ortalama puanları elde edilmiştir. Dışa dönüklük alt boyutu ortalama puanları yükseldikçe intihar riskinin $\operatorname{arttığ} 1(\mathrm{r}=0.241, \mathrm{p}=0.03)$, BBİÖ puanların da anlamlı olarak arttı $\breve{g}_{1}(\mathrm{r}=0.330, \mathrm{p}=0.03)$ saptanmıştır. Nörotisizm alt boyutunda alınan puanlar arttıkça BBİÖ puanlarının azaldığı $(\mathrm{r}=-0.238, \mathrm{p}=0.03)$ görülmüştür. KSDÖ puanları incelendiğinde ise en yüksek 9 , en düşük 0 puan olmak üzere, ortalama puanı $2.76 \pm 2.5$ 
olarak bulundu. BB tip 1 için ortalama puan $2.75 \pm 2.3$ iken, BB tip 2 için $2.85 \pm 4.5$ bulundu. Geçirilen manik dönem sayısı ile anlamlı orta düzeyde bir negatif ilişki bulunmuştur( $(\mathrm{r}=-0.30, \mathrm{p}=0.02)$. Koruyucu sağaltım süresinin artması ile KSDÖ puanlarının arttığı görülmüştür( $\mathrm{r}=-0.31, \mathrm{p}=0.01)$. Kadınlarda KSDÖ ortalama puanı $2.70 \pm 3.8$, erkeklerde ise $2.91 \pm 5.6$ bulunmuştur. Boşanmış/ dul ya da ayrı yaşayan grupta en düşük KSDÖ ortalama puanları elde edilmiştir. Evli olanlar için $3.23+2.3$, boşanmış/dul ya da ayrı yaşayan için ise, 2.88+3.3 KSDÖ ortalama puanları elde edilmiştir. Post hoc testi ile ilk kıyaslamaları yapıldığında; sirasıyla $(r=-2.98, p=0.01, r=-2.53, p=$ 0.03 ) anlamlı farklılıklar olduğu saptanmıştır. Buna göre boşanmış/ dul ya da ayrı yaşayan grupta koruyucu sağaltıma yanıt en düşüktür. BBİÖ ile KSDÖ ortalama puanları arasında anlamlı pozitif korelasyon saptanmıştır $(\mathrm{r}=0.394, \mathrm{p}<0.01)$. BBİÖ alt alan ortalama puanları incelendiğinde, KSDÖ puanı ile en kuvvetli ilişkinin duygusal işlevsellik $(r=0.401, \quad p<0.001)$ alt grubunda olduğu; bunun yanı sıra arkadaşları ile ilişkiler, günlük etkinlikler ve hobiler, insiyatif alma ve potansiyelini kullanabilme ve iş alanındaki işlevselliklerin değerlendirildiği alt gruplar hariç diğer tüm alt gruplarda anlamlı pozitif ilişkiler olduğu gözlenmiştir. KSDÖ ölçeği puanları ile EKAGGK ölçeği alt alan puanları arasındaki ilişkinin değerlendirilmesi Tablo 3'de verilmiştir.

Tablo 3. KSDÖ ölçeği puanları ile EKA-GGK ölçeği alt alan puanları arasındaki ilişkinin değerlendirilmesi

\begin{tabular}{|l|c|c|}
\hline $\begin{array}{c}\text { EKA-GGk ölçeği } \\
\text { alt alanı }\end{array}$ & Korelasyon katsayısı (r) & p \\
\hline Nörotisizm & $-0,02$ & $>0,05$ \\
\hline Psikotisizm & $-0,23$ & 0,04 \\
\hline Dı̧̧adönüklük & 0,10 & $>0,05$ \\
\hline
\end{tabular}

\section{Tartışma}

Hastadan hastaya değişebilen doğal seyrinin karmaşıklığı ve belirsizliği gibi hastaya ait biyolojik, psikososyal etmenlerin yanı sıra ilaç seçimi, ilaç uyumu ile ilacın etkinliği, ilaç yan etkileri BB tedavisini etkileyebilen durumlardır. Bugün halen koruyucu sağaltım ile ilgili bilgilerin yeterli olduğunu söylemek mümkün değildir. Bizim çalışmamızda BB tanılı hastalarda koruyucu tedaviyi etkileyebileceği düşünülen kişilik özellikleri ile koruyucu sağaltım yanıtları arasındaki ilişki incelenmiştir. Çalışmamıza dahil edilen olgular sosyodemografik özellikler açısından değerlendirildiğinde; ilk göze çarpan bulgu cinsiyet dağılımındaki farklılıktı. BB tanılı kadınlarla erkeklerde eşit oranlarda görüldüğü düşünülmektedir $(18,19)$. Ancak, BB fenomenolojisinde cinsiyet farkl111kları yeterince çalışılmamıştır ve çelişkili sonuçlar vardır. Hastalığın her iki cinste eşit görülmesine karşın klinik özellikleri ve gidişinde çeşitli cinsiyet farklılıkları bulunmaktadır (20-22). BB için bizim örneklemimizde \%71.3'e \%28.7 şeklinde kadın hasta lehine bir yaygınlık farkı vardı. Ülkemizde yapılan çalışmalar incelendiğinde ise, bir çalışmada olguların \% 54'ü erkek, \% 46'sı kadın olarak bildirilmiştir (23). Çeşitli araştırmalardaki BB tanısıyla izlenen hastaların cinsiyet özelliklerine bakıldığında; Kessing'nin yaptığı bir çalışmada 1719 hastadan oluşan grupta \% 45. 8 erkek, \% 54. 2 kadın oranı belirlenmiş̧tir (24). Bir diğer başka bir çalışmada \% 44 erkek oranına karşın, $\% 56$ kadın oranı belirlenmiştir (25). Stanley Foundation Bipolar izleme çalışmasında 261 hastanın \% 56'sının kadın \% 44'ünün erkek olduğu bildirilmiştir (26). Ülkemizde Özerdem ve ark.(2001) yaptığı bir çalışmada yatarak tedavi gören BB tanılı hastaların \% 55.3'ü kadın , \% 44.7'si erkek

Genel Tip Derg 2021;31(3)189-195 olarak bildirilmiştir (27). Ülkemizde yapılan bir başka çalışmada ise, 260 hastanın \% 51.2 'si erkek, \% 48.8'i kadın olarak saptanmıştır (28). Diğer çalı̧̧malardan farklı olarak bizim çalışmamızda kadın ve erkek hastalar arasında önemli farklılık dikkat çekicidir. Bu fark, kısmen erkeklerin muayeneye tek başına gelip yaklaşık 1.5 saat sürecek olan görüşmelere girmeye gönüllü olmaması, kısmen bölgedeki kültürel özellik olarak kimi manik dönem belirtilerinin "bölgeye has kişilik özellikleri” sayılıp bir hastalık olarak kabul görmemesi bunun devamında da bir tanı alıp tedavi görüyor olmaması, kısmen de örneklemimizin küçüklüğü ile açıklanabilir. Çalışmamıza dahil edilen olguların eğitim düzeyi incelendiğinde sadece \% 25 'nin yükseköğretim düzeyine sahip olduğu sonucu elde edildi. Ülkemizde yapılan iki çalışmada lise ve yüksek öğretim düzeyi \% 84 olarak bildirilmiştir $(23,28)$. Bizim çalışmamızdaki daha düşük oranlar olgularımızın çoğunluğunu kadın hastaların oluşturması ve bölgemizdeki kadınların düşük eğitim düzeyi ile açıklanabilir. Özellikle erken başlangıçlı BB akademik başarıyı olumsuz etkilemektedir. Çok sayıdaki çalışmada da hastaların genel topluma göre ortalama eğitim yılının daha düşük olduğu rapor edilmiştir (30-32).

Çalışmamızda 25 hastanın psikiyatrik eştanısının olduğu, ilk sırada OKB tanısının yer aldığ 1 izlendi. BB tanılı hastalarda psikiyatrik eştanı sık görülen bir durumdur. Konu ile ilgili bir çalışmada eş tan1 oran1 \%65 ve anksiyete bozuklukları oran1 ise \% 42 olarak bildirilmiştir (33). BB tip 1 tanılı hastalarla yapılan bir çalışmada da çalışmamızın bulgularını destekler şekilde \% 39 OKB, \% 26 özgül fobi, \% 20 sosyal fobi olmak üzere anksiyete bozukluğu eş tanıs1 \% 61.4 olarak bildirilmiştir (34). Yine benzer şekilde ülkemizde yapılan bir çalışmada hastaların \% 46'sında eştanı bulunduğu ve en sık (\% 22) görülen eş tanının OKB, sosyal fobi ( $\% 20)$, panik bozukluk ( $\%$ 12) olarak saptandığı rapor edilmiştir (23). Bu çalışma da olduğu gibi bizim çalışmamızda da OKB en sık eştanılı durumdur. Çalışmamızda hastaların 33'ünün (\%41.3) birinci derece akrabalarında ruhsal hastalık öyküsü mevcuttu. BB kalıtımsal yatkınlık gösteren bir bozukluktur ve birinci derece akrabalarda bir duygudurum bozukluğu görülme sıklığı normal popülasyona göre 8-18 kat daha fazla olarak bildirilmektedir (35). Ülkemizde yapılan bir çalışmada ailede ruhsal hastalık öyküsü \% 68 olarak bulunmuştur (23). Ülkemizde yapılan bir diğer çalışmada ise hastaların ikinci derecede akrabalarında BB 8 (\%10) en sık görülen ruhsal bozukluk olarak bildirilmiştir (1). Bu sonuçlar çalışmamızın bulguları ile benzer özelliktedir. BB için genetik bir geçiş olduğuna ait pek çok verinin olması da bu sonuçları destekler niteliktedir. Ayrıca bölgemizde çok yaygın görülen akraba evlilikleri de bu durumu kolaylaştırıcı bir etken olarak değerlendirilebilir.

Çalışmamızda hastaların tanısal özelikleri incelendiğinde 67 hasta (\%83.7) BB tip 1, 13(\%16.3) hasta ise BB tip 2 tanısı ile izlendiği saptanmıştır. Benzer şekilde ülkemizdeki 2 çalışmada da olguların \% 81'i ve \%94.2'inin BB tip 1 tanısı ile izlendiği bildirilmiştir $(1,36)$. Çalışmamızda BB tip1 tanısı ile izlenen olguların \%57.5 kadın, \%26.3 erkekti. Bizim çalışmanın bulgularını destekler nitelikte ülkemizde yapılan iki çalışmada da BB tip 1 tanılı hastaların çoğunluğunu kadınların oluşturduğu belirtilmiştir $(1,37)$. Aslında konu ile ilgili yazın incelendiğinde kadınların daha çok BB tip 2 tanısını aldıkları ve daha yüksek oranda depresif dönem geçirdiği belirtilmektedir $(38,39)$. BB tip 2 sıklığının düşük olması ise BB tip 2'nin klinisyenler tarafından daha az tanınması ya da hasta başvurularının daha az olmasına bağlı olabilir. Çalışmalarda BB tip1 tanısının daha yüksek oranlarda yer almasında özellikle mani dönemlerinin şiddetli olması hastaların kliniğe başvurularını artırması ve buna bağlı olarak da daha 
erken tanı almalarında rol oynayan bir durumdur. Çalışmamıza dahil edilen olguların ortalama hastalık süresi $13.8 \pm 9.1$ yıldı. Ortalama hastalık süresi kadınlarda 14.63 \pm 9.4 , erkeklerde $11,87 \pm 8.2$ y1l idi. Ülkemizde yapılan bir çalışmada hastaların ortalama hastalık süresi kadınlarda ortalama $11.5 \pm 8.46$ y1l, erkeklerde ise ortalama $11.6 \pm 7.91$ yıl olarak belirtilmiştir (1). Bir başka çalışmada ortalama hastalık süresi kadın olgular için $9.7 \pm 13.2$ y1l, erkek olgular için $6.4 \pm 7.8$ yıl olarak bildirilmiştir (41). Bir başka çalışmada ise ortalama hastalık süresi $8.4 \pm 7.9$ yıl olarak saptanmıştır (23). Bizim çalışmamızın bulgularına yakın bir oran elde edilen bir diğer çalışmada hastalık süresi ortalaması $14.3 \pm 8.7$ yıl olarak bildirilmiştir (28). Diğer yandan ülkemizde yapılan bir başka çalışmada ise hastalık süresi ortalama $15.39 \pm 8.10$ y1l olarak rapor edilmiştir (36). Çalışmamızda kadın olgularda hastalığın başlangıç yaşı $26.28 \pm 4.1$, erkek olgularda ise $27.65 \pm 3.9$ yıl olarak saptanmıştır. Ülkemizde yapılan bir çalışmada hastalık başlangıç yaşı kadınlarda $28.7 \pm 9.7$, erkek hastalarda 22.5 \pm 6.9 y1l olarak belirtilmiştir (40). Konu ile ilgili literatür gözden geçirildiğinde kadınlarda mani ve BB başlangıç yaşının daha geç olabileceği öne sürülmüştür. Örneğin, BB tip1 veya BB tip2 tanılı 360 hasta ile yapılan bir çalışmada kadınların başlangıçta erkeklere göre 3,2 yaş daha büyük oldukları bildirilmiştir (41). Çalışmamızda kadın ve erkekler arasında hastaneye yatış sayısı açısından anlamlı bir farklılık saptanmamıştır. Ülkemizde yapılan bir çalışmada da benzer şekilde ortalama hastaneye yatış sayısı kadın hastalar için $1.64 \pm 2.26$, erkek hastalar için $1.44 \pm 1.57$ olarak bildirilmiştir (1). Bir başka çalışmada ise hastaneye yatış sayısı ortalama $2.53 \pm 2.4$ olarak belirtilmiştir (36).

Çalışmamızda kadın ve erkekler arasında geçirilen hastalık dönemi açısından anlamlı bir farklılık yoktu. BB tanılı kadın hastaların erkeklere oranla depresyon dönemi geçirmeye daha yatkın oldukları kabul edilen bir görüştür. Bununla birlikte BB'da cinsiyet farklılıkları nispeten ihmal edilmiş bir konudur. BB kadın ve erkekte eşit sıklıkta görülmekle birlikte, hastalık gidişinde önemli cinsiyet farkl1lıkları vardır. BB tanılı kadınlarda depresyon ve hızlı döngü daha sıktır. Ayrıca hastalığın daha geç (yaşamın beşinci dekadında) başlaması ve öforikten daha çok disforik mani görülmesi kadında daha sıktır. Kadının üreme döngüsünün çeşitli evreleri yalnız hastalık gidişini etkilemekle kalmayıp tedaviyi de etkiler (42). Bu durumu destekler nitelikte 16 yıllık bir izlem çalışmasında BB tanılı erkek hastaların dönemlerinin \%35'ini mani, \%36'sını depresyon olarak geçirdikleri, kadınların ise \%14'ünü mani ve \%60'ının depresyon olarak geçirdikleri bildirilmiştir (39). Aynı çalışmada kadınlara göre erkeklerin mani nedeni ile daha çok hastaneye yattıkları belirlenmiştir. Cinsiyet farklılıklarını belirlemeye yönelik sekiz yıllık bir izlem çalışmasında dönem alt tipi açısından belirgin cinsiyet farklılığ saptanmamıştır (24) . Çalışmamızda $31(\% 38,8)$ hastada mevsimsel özellik, 40 hastada (\%50) psikotik özellik, 20 hastada (\%25) intihar girişimi öyküsü vardı. Ülkemizdeki bir çalışmada ise, hastalığın uzun dönemdeki seyrinde en s1k şiddetli ve psikotik özellikli seyrettiği (\% 55), mevsimsel özellik (\% 69) gösterdiği, hastaların \% 19'unda intihar girişimi olduğu belirtilmiştir (1). Diğer bir çalışmada ise hastalık süreci ile ilgili özellikler değerlendirildiğinde; 21(\% 42) hastada mevsimsel özellik, 40 (\% 80) hastada psikotik özellik bulunduğu rapor edilmiştir (23). BB tanılı hastaların yüksek oranlarda intihar girişiminde bulunduğu ve intihar sonucu hayatlarını kaybetme olasılığı genel toplumun 20 katıdır (2). Bizim çalışmamızda olguların \% 25'sinde intihar girişimi öyküsü saptanmıştır. Ülkemizde yapılan iki ayrı çalışmada da benzer şekilde olguların \%19'unda ve $\% 22$ 'sinde intihar girişimi saptanmıştır $(1,23)$.
Çalışmamıza hastalardan yalnızca 15 'i (\%18.6) tedavisine monoterapi şeklinde devam etmekteydi. Ülkemizde yapılan bir çalışmada ise; 12 hasta (\%31.5) sadece tekli duygudurum dengeleyici kullandığı bildirilmiştir (23). Çoklu ilaç tedavisi ile ilgili yüksek oranlar açısından bizim çalışmamızın bulgularını destekler niteliktedir. Bu alanda yapılan bir başka çalışmada ise, koruma döneminde en sık lityumun (\%43.58) tercih edildiği, takiben valproik asit (\%28.19) ve kombine duygudurum dengeleyici kullanımı (\%14.74) izlediği, en az tercih edilen duygudurum dengeleyici ise karbamazepin (\%11.53) olduğu, duygudurum dengeleyicilere sıklıkla bir antipsikotiğin eşlik ettiği ilaç kombinasyon oranın da oldukça yüksek (\% 62.2), bunun da \% 41'i atipik antipsikotikler, \% 19.2'si tipik antipsikotikler olduğu rapor edilmiştir (1). Bu çalışmadaki yüksek lityum kullanım oranı ve bizim çalışmamızın bulguları ile uyumludur. BB sağaltım kılavuzlarında lityumun ilk sıra ilacı olarak yer alması klinisyenlerin ilaç seçimini etkilemektedir.

Çalışmamızda KSDÖ ortalama toplam puanlarının oldukça düşük olduğu saptanmıştır. Ülkemizde yapılan bir çalışmada ise, hastaların çoğunluğu (\%30.7) monoterapi duygudurum dengeleyici ilaç kullanmakta olduğu ve koruyucu sağaltıma da en çok bu grupta yer alan hastaların yanıt verdiği, valproik asit ve antipsikotik ile karbamazepin ve antipsikotik gruplarında yer alan hastaların hiçbiri koruyucu sağaltıma tam yanıt vermediği, tüm gruplarda yer alan hastalarda koruyucu sağaltıma kısmi yanıt oranlarının çok yüksek olduğu, KSDÖ puanlarını duygudurum dengeleyiciler ek olarak antipsikotik kullanımının bulunması toplam puanı düşürdüğü bildirilmiştir (1). $\mathrm{Bu}$ bulgular bizim çalışmamızın bulguları ile uyumlu değildir. $\mathrm{Bu}$ durum çalışmaya dahil edilen olguların tedavi uyumlarının iyi olmaması ile açıklanabilir. Günümüze kadar yapılan çok sayıdaki çalışmaların verileri dikkate alındığında, duygudurum dengeleyici ilaç kullanımının korumada rolünün önemi tartışılmaz. Örneğin bir çalışmada yeni bir dönem geçirme oranı lityum koruması ile $\% 32$, valproik asit koruması ile \% 18 oranında azalma olduğu bildirilmiştir (42). Bir başka çalışmada ise ortalama 4.2 yıl koruyucu sağaltım süresi sonrasında hastalıkla geçen süre \% 22'ye düşmüştür (43). Bizim çalışmamızda manik dönem ortalaması yüksek olan hastalarda lityum ilk tercih olarak seçilmiştir. Literatürde de lityumun manik dönemleri önlemede daha etkin olduğu bildirilmektedir (4446).

BB tanılı hastaların kişilik özellikleri de birçok çalışmaya konu edinilmiştir (47-49). Bizim çalışmamızda hastalara uygulanan EKAGGK sonucunda, nörotisizm alt boyutunda $3.14 \pm$ 1.3, dişa-dönüklük alt boyutunda $1.84 \pm 1.6$, psikotisizm alt boyutunda ise $1.59 \pm 1.2$ ortalama puanları saptanmıştır. Ülkemizde yapılan bir başka çalışmada BB için bu boyutların ortalama değerleri nörotisizm, dışa dönüklük ve psikotisizm için sırasıyla $4.3,3.8$ ve 1.5 şeklinde bulunmuştur (50). Çalışmamızın ilginç bulgularından biri, literatürde daha önceden çalışılmış olan Akiskal'ın hipertimik mizacı ile Cloninger'in yenilik arama alt ölçeği benzer öğeler taşıyan dişa dönüklük boyutundan alınan düşük ortalama puanıdır. Oysa gözleme dayalı olası tarihsel ilişkisi bir yana, önceki çalışmalarda BB ile hipertimik mizaç arasında güçlü bir ilişki olduğu vurgulanmıştır (51). Akiskal'ın, daha çok depresyon ile ilişkilendirilen, depresif ve endişeli mizacı ile benzer öğeler taşıyan nörotisizm boyutundaki ortalama puanlar ise görece yüksektir (52). Bu durum bizim örneklemimizdeki hastaların, hastalıktaki depresif ucunun daha baskın olmasından kaynaklanıyor olabilir. Ayrıca depresif baskınlık ve örneklemimizin nörotisizm puanlarının yüksek olması, her ne kadar istatistiksel analize yansımış 
olmasa da, ortalama KSDÖ puanlarının önceki çalışmalara göre biraz daha düşük bulunmuş olmasını da kısmen açıklayabilir. Koruyucu tedaviye yanıtlar incelendiğinde istatistiksel olarak anlamlı sayılmasa da dışa dönüklük puanı ile koruyucu tedaviye yanıt puanı arasında beklendiği gibi pozitif bir ilişki bizim çalışmamızda da saptanmıştır. Benzer olarak bir çalışmada da lityumun koruyuculuğu ile hipertimik mizaç özellikleri arasında pozitif, kaygılı ve siklotimik mizaç özellikleri arasında ise negatif bir ilişki bulunmuştur (53). Hipertimik mizacın yatkınlık yaratan genetik altyapısı düşünüldüğünde bazı ailelerde lityuma neden çok daha iyi cevap alındığı belki de daha iyi anlaşılabilir (54). Çalışmada koruyucu sağaltıma yanıt puanı ile istatistiksel olarak anlamlı ilişki gösteren tek EKA-GGK alt boyutu psikotisizm olarak bulunmuştur. Örneklemimizde psikotisizm alt ölçeği puanlar arttıkça, koruyucu sağaltıma verilen yanıtın azaldığı görülmektedir.

$\mathrm{Bu}$ çalışmanın bazı kısıtlıkları mevcuttur. Çalışmanın kesitsel, hastaların tek bir merkezden seçilmiş olması genelleme yapılmasını olanaksız kılmaktadır. Ayrıca çalışmaya alınan olguların rastgele seçilmesi belli ölçütleri karşılayan, benzer özellikteki olguların bir araya gelmesini engellemiştir. Çalışmayla ilgili diğer bir kısıtllılı da sağaltım yanıtlarını değerlendirme amacıyla kullanılan ölçeklerin daha önce az sayıda çalışmada kullanılmış ölçütler olmasıdır. Özellikle KSDÖ ile ilgili daha kapsamlı çalıșmalara ihtiyaç vardır.

\section{Sonuç}

BB işlevsellikte bozulmaya yol açan, intihar riskini oldukça arttıran, beraberinde ciddi ek tanılı ve komplikasyonlar getirebilen, gidişat öngörülmesi neredeyse imkansız kronik bir ruhsal bozukluktur. $\mathrm{Bu}$ nedenle BB tanısını mümkün olduğunca çabuk ve doğru koymak ve koruyucu sağaltımı düzenlemek hayati önem taşır. BB koruyucu sağaltımına etki eden birçok faktörün olduğu bilinmektedir. Bu çalışmada özellikle psikotisizm özelliği olan kişilik özelliklerinin BB koruyucu sağaltım ve işlevsellik üzerine etkisinin olabileceği bulguları elde edilmiş olup, kişilik özelliklerinin belirleyici rolünün yerinin ve büyüklüğünün tam olarak saptanabilmesi için geniş örneklemli yeni çalışmalara ihtiyaç vardır.

\section{Çıkar Çatışması ve Finansal Destek Beyanı}

Bu yazıdaki hiçbir yazarın herhangi bir çıkar çatışması yoktur. Yazının herhangi bir finansal desteği yoktur.

\section{Kaynaklar}

1.Eroğlu ZM, Özpoyraz N. Bipolar bozuklukta koruyucu tedavi. Psikiyatride Günce Yaklaşımlar 2010; 2: 206-36.

2.Yeloğlu HÇ, Hocaoğlu Ç. Önemli bir ruh sağlığı sorunu: Bipolar bozukluk. Mustafa Kemal Üniversitesi Tıp Dergisi 2017; 8: 41-54.

3. Prajapati AR, Dima AL, Clark AB, et al. Mapping of modifiable barriers and facilitators of medication adherence in bipolar disorder to the Theoretical Domains Framework: a systematic review protocol. BMJ Open 2019; 9:e26980.

4. Gitlin M. Treatment-resistant bipolar disorder. Mol Psychiatry 2006;11:227-40.

5.Woo YS, Yoon BH, Song JH, et al. Clinical correlates associated with the long-term response of bipolar disorder patients to lithium, valproate or lamotrigine: A retrospective study. PLoS One 2020;15: e0227217.

6. Sayın A, Aslan S. Duygudurum bozuklukları ile huy, karakter ve kişilik ilişkisi. Turk Psikiyatri Derg 2005; 16:276-83.
7 Bellivier F, Delavest M, Coulomb S, et al. Therapeutic management of bipolar disorder in France and Europe: A multinational longitudinal study (WAVE-bd) Encephale 2014;40:392-400.

8. Grunze H, Vieta E, Goodwin GM, et al. The World Federation of Societies of Biological Psychiatry (WFSBP) guidelines for the biological treatment of bipolar disorders: update 2012 on the long-term treatment of bipolar disorder. World J Biol Psychiatry $2013 ; 14: 154-219$

9.First MB, Spitzer RL, Gibbon M. Structured Clinical Interview for DSM-IV Clinical Version (SCID-I CV). Washington: American Psychiatric Press; 1997: s: 1-87.

10. Çorapçığlu A, Aydemir Ö, Yıldız M ve ark. DSM-IV eksen 1 ruhsal bozukluklarına göre Türkçe yapılandırılmış klinik değerlendirmenin güvenirliği. İlaç ve Tedavi Dergisi $1999 ; 12: 33-6$

11. Young RC, Biggs JT, Ziegler VE, et al. A rating scale for mania: reliability, validity and sensitivity. Br J Psychiatry 1978; 133: 429-35.

12. Karadağ F, Oral ET, Aran YF ve ark. Young Mani Derecelendirme Ölçeğinin Türkiye'de geçerlik ve güvenilirliği. Türk Psikiyatri Derg 2002; 13: 107-14.

13. Akdemir A, Örsel DS, Dağ İ, ve ark. Hamilton Depresyon Derecelendirme Ölçeği (HDDÖ)'nin geçerliği-güvenirliği ve klinikte kullanımı. 3P Dergisi 1996; 4:251-9.

14. Aydemir Ö, Eren İ, Savaş H ve ark. Bipolar Bozuklukta İşlevsellik Ölçeğinin Geliştirilmesi, güvenilirlik ve geçerliliği. Türk Psikiyatri Derg 2007; 18: 344-52.

15. Grof P, Duffy A, Cavazzoni P, et al. Is response to prophylactic lithium a familial trait? J Clin Psychiatry 2002;63:942-7.

16. Francis LJ, Brown LB, Philipchalk R. The development of an abbreviated form of the Revised Eysenck Personality Questionnaire (EPQR-A): its use among students in England, Canada, the USA and Australia. Pers Individ Dif 1992; 13: 443-9.

17.Karanc1, N, Dirik G, Yorulmaz O. Eysenck Kişilik Anketi-Gözden Geçirilmiş̧ Kısaltılmıș Form Türkiye'de geçerlik ve güvenirliği. Türk Psikiyatri Derg 2007; 18:23 32

18. Baldassano CF, Marangell LB, Gyulai L, et al. Gender differences in bipolar disorder: retrospective data from the first 500 STEP-BD participants. Bipolar Disord 2005; 7:46570

19. Amihăesei IC. Bipolar disorder, not so rare diagnosis: subtypes of different degrees of severity, diagnosis, therapy. Rev Med Chir Soc Med Nat Iasi 2014;118:111-5.

20.Diflorio A, Jones I. Is sex important? Gender differences in bipolar disorder. Int Rev Psychiatry 2010;22:437-52.

21.Braunig P, Sarkar R, Effenberger S, Schoofs N, Kruger S. Gender differences in psychotic bipolar mania. Gend Med 2009; 6:356-61.

22. Hendrick V, Altschuler LL, Gitlin MJ, Delrahim S, Hammen C. Gender and bipolar illness. J Clin Psychiatry 2000; 61:393-6.

23. Turhan N.Bipolar bozukluk:Kesitsel bir değerlendirme.Uzmanlık tezi.Çukurova Üniversitesi yayınları, Adana; 2007.

24. Kessing LV. Gender differences in the phenomenology of bipolar disorder. Bipolar Disord 2004; 6: 421-5.

25. Kupka RW, Luckenbaugh DA, Post RM, et al. Comparison of rapid-cycling and nonrapid-cycling bipolar disorder based on prospective mood ratings in 539 outpatients Am J Psychiatry 2005; 162:1273-80.

26. The stanley Foundation Bipolar Network II. Br J Psychiatry 2001; 178:177-83.

27 Özerdem A, Tunca Z, Kaya N.The relatively good prognosis of bipolar disorders in a Turkish bipolar clinic. J Affect Disord 2001; 64: 27-34.

28. Gülşen G. Bipolar bozukluk: 14 yıllık dönemin değerlendirilmesi. Uzmanlık tezi, Çukurova Üniversitesi, Adana; 2004.

29. Akkaya C, Altın M. Türkiye'de bipolar I bozukluğu hastalarının, sosyodemografik ve klinik özellikleri-HOME Çalışması. Klinik Psikofarmakoloji Bülteni 2012;22:31-42.

30. Akkaya C, Altın M. Türkiye'de bipolar I bozukluğu hastalarının, sosyodemografik 
ve klinik özellikleri-HOME Çalışması. Klinik Psikofarmakoloji Bülteni 2012;22:31-42.

31. Yazla E, İnaç L, Bilici M. İki uçlu bozukluk manik dönemdeki hastalarda sosyodemografik özellikler, klinik belirtiler ve işlevsellik seviyesinin birbiriyle ilişkisi ve cinsiyete göre farklılıkları. Düşünen Adam: Psikiyatri ve Nörolojik Bilimler Dergisi 2012;25:221-9.

32. Mantere O, Suominen K, Leppämäki S, et al. The clinical characteristics of DSM-IV bipolar I and II disorders: baseline findings from the Jorvi Bipolar Study (JoBS). Bipolar Disord 2004; 6: 395-405.

33. McElroy, Susan L, Lori L, et al. Axis I psychiatric comorbidity and its relationship to historical illness variables in 288 patients with bipolar disorder. Am J Psychiatry 2001; 158: $420-6$.

34. Tamam L, Ozpoyraz N. Comorbidity of anxiety disorder among patients with bipolar I disorder in remission. Psychopathology 2002; 35: 203-9.

35. Baron M. Genetic linkage and bipolar disorder. J Affect Disord 2001; 67: 267-373.

36. Canbazoğlu M, Akkaya C, Cangür Ş, Kırlı S. The effect of residual symptoms on clinical characteristics and functioning of patients with bipolar disorder in remission. Anadolu Psikiyatri Derg 2013; 14): 228-36.

37. Keck PE Jr, McElroy SL, Strakowski SM, et al. Outcome and comorbidity in firstcompared with multiple-episode mania J Nerv Ment Dis 1995; 183:320-4.

38. Viguera AC, Baldessarini RJ, Tondo L. Response to lithium treatment in bipolar disorders: comparison of women and men. Bipolar Disord 2001; 3;245-52.

39. Liebenluft E. Women with bipolar illness: clinical and research issues. Am J Psychiatry 1996; 153: 163-73.

40.Akarsu S, Erdem M, Bolu A, Günay H,Garip B. Bipolar bozuklukta cinsiyete göre klinik ve sosyodemografik özelliklerin karşılaştırılması. Gülhane Tıp Derg 2012; 54: 27983.

41 Viguera AC, Baldessarini RJ, Tondo L. Response to lithium treatment in bipolar disorders: comparison of women and men. Bipolar Disord 2001; 3;245-52.

42. Smith LA, Cornelius V, Warnock A, Bell A, Young AH. Effectiveness of mood stabilizers andantipsychotics in the maintenance phase of bipolar disorder: a systematic review of randomized controlled trials. Bipolar Disorder 2007; 9:394-412.

43. Baldessarini RJ, Tondo L, Hennen J, Floris G. Latency and episodes before treatment: response to lithium maintenance in bipolar I and II disorders. Bipolar Disord 1999; 2:91-

44. Won E, Kim YK. An Oldie but Goodie: Lithium in the treatment of bipolar disorder through neuroprotective and neurotrophic mechanisms. Int J Mol Sci 2017;18:2679.

45. Curran G, Ravindran A. Lithium for bipolar disorder: a review of the recent literature. Expert Rev Neurother 2014;14:1079-98.

46. Vazquez-Montes MDLA, Stevens R, Perera R, Saunders K, Geddes JR. Control chart for monitoring mood stability as a predictor of severe episodes in patients with bipolar disorder. Int J Bipolar Disord 2018;6:7.

47. Üçok A, Karameli D, Kundakçı T. Comorbidity of personality disorders with bipolar mood disorders. Compr Psychiatry 1997; 39: 72-4.

48.Smillie LD, Bhairo Y, Gray J, et al. Personality and the bipolar spectrum: normative and classification data for the Eysenck Personality Questionnaire-Revised. Compr Psychiatry 2009; 50:48-53.

49.Lewis M, Scott J, Frangou S. Impulsivity, personality and bipolar disorder. Eur Psychiatry 2009; 24:464-9.

50.Güleç H, Tamam L, Usta H, Saygılı İ ve ark. Bipolar bozuklukta dürtüsellik Anatolian Journal of Psychiatry 2009; 10:198-203.

51. Kesebir S, Vahip S, Akdeniz F, Yüncü Z. Bipolar bozuklukta mizaç ile klinik özelliklerin ilișkisi. Türk Psikiyatri Derg 2005; 16:164-9.

52. Akiskal HS, Placidi GF, Maremmani I, et al. TEMPS-I: delineating the most discriminant traits of the cyclothymic, depressive, hyperthymic and irritable temperaments in a nonpatient population. J Affect Disord 1998; 51:7-19.
53.Rybakowski JK, Dembinska D, Kliwicki S, Akiskal KK, Akiskal HH. Temps-a and long term lithium response: positive correlation with hyperthimic temperament. J Affect Disord 2013; 145:87.

54. Savitz J,Merwe LVD, Ramesar R. Personality endophenotypes for bipolar affective disorder: a family-based genetic association analysis. Genes, Brain and Behaviour 2008; 7:869-76

Bipolar Bozuklukta koruyucu tedavi ve işlevsellik - Yeloğlu ve ark. 